\title{
Optimalisasi Bimbingan Klien Pemasyarakatan Pada Masa Pandemi Covid-19 di Balai Pemasyarakatan (Studi di Balai Pemasyarakatan Kelas I Jakarta Selatan)
}

\author{
Yuniati Maryana Tahamata ${ }^{1}$ \\ ${ }^{1}$ Balai Pemasyarakatan Kelas I Jakarta Selatan, Kemenkumham Republik Indonesia \\ Corresponding author. Email : yuniati.maryana@gmail.com
}

Naskah diterima: 26-01-2021 revisi: 17-11-2021; disetujui: 30-11-2021

DOI: https://doi.org/10.46257/jrh.v25i2.195

\begin{abstract}
Abstrak
Pandemi Covid-19 dengan korban yang semakin menigkat, berdampak pada pelaksanaan proses peradilan yang ada di Indonesia. Hal ini juga terjadi pada proses bimbingan klien pemasyarakatan. Penelitian mengambil rumusan masalah bagaimana pelaksanaan optimalisasi dan kendala bimbingan klien pada masa pandemi di Bapas. Selain itu, penelitian bertujuan untuk mengkaji upaya mengoptimalkan pembimbingan oleh Pembimbing Kemasyarakatan pada masa pandemi Covid-19 di Balai Pemasyarakatan Kelas I Jakarta Selatan sehingga hak klien pemasyarakatan bisa terpenuhi dengan tetap memperhatikan protokol kesehatan. Penelitian ini merupakan penelitian deskriptif dengan metode penelitian kualitatif. Teknik pengumpulan data yang digunakan adalah wawancara, observasi, dan studi kepustakaan. Pengambilan subyek penelitian menggunakan teknik purposive sampling yaitu ditetapkan atas dasar tujuan tertentu yang mempunyai hubungan erat dengan masalah yang diteliti, yaitu Kepala Subseksi Bimbingan Klien Dewasa, Pembimbing Kemasyarakatan dan Klien Pemasyarakatan. Teknik keabsahan data menggunakan cross check dari hasil wawancara dan studi kepustakaan. Analisis data yang digunakan menggunakan analisis induktif dengan tahap reduksi data, unitisasi dan kategorisasi, serta pengambilan kesimpulan. Hasil penelitian ini menunjukkan bahwa selama masa pandemi Covid-19 terdapat beberapa perubahan prosedur pelaksanaan bimbingan klien yang dulunya dilakukan secara tatap muka menjadi melalui daring. Pembimbingan klien difokuskan pada peningkatan ketaqwaan kepada Tuhan Yang Maha Esa, peningkatan kesadaran hukum serta penanaman pola hidup bersih dan sehat guna mencegah penyebaran Covid-19. Kesimpulan penelitan menemukan kendala yang muncul selama proses pembimbingan daring ini meliputi terbatasnya informasi untuk kebutuhan asesmen, keterbatasan pemahaman petugas akan pentingnya laporan perkembangan dan asesmen, serta partisipasi klien rendah. Saran untukmelakukan optimalisasi proses pembimbinngan tersebut adalah dengan meningkatkan koordinasi dengan Aparat Penegak Hukum dan Pemerintah Daerah, peningkatan kualitas Sumber Daya Manusia, serta meningkatkan kualitas dan intensitas bimbingan.
\end{abstract}

Kata kunci: pandemi, balai pemasyarakatan, pembimbingan, klien. 


\title{
Optimization of Correctional Client Guidance During the Covid- 19 Pandemic at Correctional Centers (Study at the Class I Correctional Center, South Jakarta)
}

\begin{abstract}
The Covid-19 pandemic, with an increasing number of victims, has an impact on the implementation of judicial processes in Indonesia. This also occurs in the correctional client guidance process. The research aims to determine the efforts to optimize guidance by Community Guides during the Covid-19 pandemic at the Class I Correctional Center in South Jakarta so that correctional client rights can be fulfilled by still paying attention to health protocols. This research is a descriptive study using qualitative research methods. Data collection techniques used were interviews, observation, and literature study. Taking research subjects using purposive sampling technique, which is determined on the basis of certain objectives that have a close relationship with the problem under study, namely the Head of Adult Client Guidance Subsection, Community Advisors and Correctional Clients. The data validity technique used cross check from the results of interviews and literature study. The data analysis used is inductive analysis with the stages of data reduction, unitization and categorization, and drawing conclusions. The results of this study indicate that during the Covid-19 pandemic there were several changes in the procedure for implementing client guidance which was previously done face-to-face to online. Client guidance is focused on increasing devotion to God Almighty, increasing legal awareness and cultivating a clean and healthy lifestyle to prevent the spread of Covid-19. The conclusion of the study found that obstacles that arise during this online mentoring process include limited information for assessment needs, limited understanding of officers about the importance of progress and assessment reports, and low client participation. Suggestions for optimizing the development process are to improve coordination with law enforcement officials and local governments, improve the quality of human resources, and increase the quality and intensity of guidance.
\end{abstract}

Keywords: pandemic, correctional center, guidance, client.

\section{Pendahuluan}

Saat ini dunia sedang dalam kondisi yang mengkhawatirkan akibat adanya Corona Viruses Desease (Covid-19) yang telah menjadi pandemi. Virus tersebut dikenal dengan sebutan Covid-19 dan telah melanda 216 negara di dunia. sebanyak 7.273.958 kasus terkonfirmasi positif dengan jumlah korban meninggal dunia sebanyak 413.372 orang. Begitupula negara Indonesia juga sedang dalam kondisi darurat pandemi Covid-19. Pembaharuan data terakhir pada tanggal 22 Februari 2021 sebanyak 1,28 juta orang positif terjangkit Covid-19 dengan jumlah pasien sembuh sebanyak 1,09 juta orang dan pasien yang meninggal dunia sebanyak 34.489 orang. Adanya pandemi Covid-19 
tentunya berdampak pada stabilitas ekonomi, sosial termasuk pada tatanan sistem peradilan pidana di Indonesia (Satgas Covid-19 Indonesia, 2021).

Menyadari adanya sebuah kedaruratan berupa pnademi yang terus terjadi, Pemerintah melalui Kementeriani Hukum dan HAM mengeluarkani kebijakan berupa Peraturan Menteri Hukum dan HAM RI No.M.HH-19 PK.01.04.04 Tahuni 2020 tentang Pengeluaran dan Pembebasan Narapidana dan Anak melalui Asimilasi dan Integrasii dalami rangkai Pencegahan dan Penaggulangan Penyebaran Covid-19. Kebijakan ini diambil berdasarkan pertimbangan untuk menjamin hak hidup Warga Binaan Pemasyarakatan selama pandemi Covid-19. Karena seperti yang diketahui bersama bahwa Lembaga Pemasyarakatan dan Rumah Tahanan Negara di Indonesia mengalami overcrowding (Indradi et al., 2020). Kondisi yang sempit sehingga warga binaan hidup berdesakan di dalam sel menjadikan peluang penularan virus antar sesama warga binaan pemasyarakatan menjadi sangat mudah. Bisa dibayangkan apabila ada 1 orang yang terinfesi virus tersebut, maka penularannya akan sangat mudah dan cepat karena kondisi tersebut, apalagi sebagian diantara narapidana tersebut termasuk kelompok rentan dimana telah berusisa lebih dari 60 tahun dan telah menjalani lebih dari 2/3 masa pidana. Melalui kebijakan ini, pemerintah memberikan asimilasi dan hak integrasi berupa pembebasan bersyarat kepada 38.822 narapidana, dengan rincian sebanyak 36.641 bebas melalui program asimilasi yang terdiri dari 35.378 narapidana dewasa dan 903 anak. Sebanyak 2.181 narapidana bebas melalui program reintegrasi dengan rincian 2.145 narapidana dewasa dan 36 anak.

Warga Binaan Pemasyarakatan yang memperoleh asimilasi atau integrasi berubah statusnya menjadi klien pemasyarakatan dan berada dalam bimbingan Balai Pemasyarakatan (Wibowo, 2020). Balai Pemasyarakatan yang selanjutnya disebut (Bapas) adalah unit pelaksana teknis pemsyarakatan yang berfungsi untuk melaksanakan bimbingan terhadap klien pemasyarakatan (Caplan, 2015). Selain menjalankan bimbingan, Bapas memiliki peran penting dalam sistem peradilan pidana. Terdapat 4 fungsi utama dari Balai Pemasyarakatan yaitu 1) Bimbingan, 2) 
Pendampingan, 3) Pengawasan, dan 4) Penelitian Kemasyarakatan, yang dilaksanakan oleh Pembimbing Kemasyarakatan (PK) dimana secara umum, PK berperan sebagai agen rehabilitasi. PK memusatkan prakteknya pada pembimbingan perorangan (casework), perawatan, dan reintegrasi masyarakat termasuk juga kegiatan pengawasan dan kontrol terhadap narapidana dan klien pemasyarakatan.

Klien asimilasi dan integrasi tidak semata-mata bebas dari Lembaga Pemasyarakatan . Ketika mereka mendapatkan hak bebas tersebut, ditetapkan pula jangka waktu (masa percobaan) dan beberapa ketentuan yang harus dijalankan selama masa bimbingan tersebut. Asimilasi diberikan dengan ketentuan klien tersebut tidak melanggar ketentuan hukum dan perbuatan lain yang tidak sesuai dengan norma-norma dalam masyarakat. Selain itu, PK diperbolehkan untuk memberikan syarat khusus terkait dengan perilaku narapidana tanpa mengurangi hak beragama dan berpolitik (Hamzah, 2016:134). Salah satu kewajiban klien pemasyarakatan adalah mengikuti pembimbingan yang telah di programkan oleh Pembimbing Kemasyarakatan melalui proses asesmen.

Program pembimbingan merupakan hal yang penting untuk diberikan kepada klien pemasyarakatan karena tidak dapat kita pungkiri bahwa klien pemasyarakatan adaah orang yang bermasalah. Klien sebagai makhluk individu dan sosial juga hidup bermasyarakat, perlu mendapat pelayanan maupun bantuan yang diperlukan. Sebagai makhluk sosial hidup saling memiliki ketergantungan terutama yang bermasalah memerlukan batuan untuk dapat hidup mandiri. Klien pemasyarakatan ini memerlukan bimbingan dengan tujuan untuk meningkatkan kondisi fisik, memantapkan mental, memantapkan hasrat untuk sembuh, serta meningkatkan peran sosialnya menjadi masyarakat yang sadar hukum sehingga tidak mengulangi pelanggaran hukum lagi.

Selama pandemi Covid-19 proses pembimbingan dilaksanakan melalui daring (online). Hal ini dilakukan dalam rangka mematuhi himbauan pemerintah untuk menjalankan pembatasan fisik (physical distancing) yaitu menjaga jarak fisik antar manusia. Tujuan dilakukannya pembimbingan secara daring yaitu 
untuk meminimalisir resiko penularan Covid-19. Tindakan ini dirasa cukup efektif untuk mengurangi kerumunan dalam satu tempat termasuk dalam hal pelaksanaan pembimbingan. Klien asimilasi dan integrasi diwajibkan menghubungi pembimbing kemasyarakatan yang menanganinya satu minggu sekali melalui video call untuk melakukan bimbingan. Untuk memastikan klien pemasyarakatan mematuhi ketentuan yang ditetapkan, Balai Pemasyarakatan bertugas untuk melakukan monitoring atau pengawasan terhadap klien tersebut. Pengawasan adalah fungsi Balai Pemasyarakatan yang pokok dalam proses penegakan hukum. Pengawasan merupakan langkah atau kegiatan yang berfungsi untuk memantau pelaksanaan program pembimbingan oleh Bapas serta mencegah penyelewengan pelaksanaan reintegrasi sosial. Pengawasan menjadi hal yang penting karena apabila klien melakukan pelanggaran atau tidak menjalankan ketentuan yang telah ditetapkan, maka narapidana yang mendapatkan asimilasi akan berpotensi melakukan tindak kejahatan kembali (residivis).

Namun pada kenyataannya, masih banyak terjadi penyimpangan yang dilakukan oleh klien antara lain tidak menjalankan pembimbingan online secara disiplin. Sering ditemukan klien yang tidak melakukan konsultasi bimbingan melalui video-call selama lebih dari 3 kali berturut-turut, sedangkan berdasarkan syarat umum yang diberikan, apabila klien tidak melakukan konsultasi sebanyak tiga kali berturut-turut dianggap sebgai sebuah pelanggaran. Rendahnya kedisiplinan klien tentu mempengaruhi intervensi perubahan perilaku klien yang berkaitan dengan potensi klien kembali melakukan tindak pidana selama dia menjalani asimilasi atau integrasi. Kondisi ini diperburuk dengan data informasi klien yang diperoleh dari Lembaga Pemasyarakatan tempat klien sebelumnya menjalani pidana tidak valid. Terdapat nomor telepon yang ternyata tidak dapat dihubungi sehingga menyulitkan PK untuk melakukan pembimbingan dan pengawasan terhadap klien tersebut.

Di Indonesia angka pengulangan tindak pidana masih sangat fluktuatif. Menurut Priyatno, pada kurun waktu tahun 1994 - 1996 tingkat residivis mencapai 5,61\%, dan mengalami kenaikan menjadi 6,63\% pada tahun 1997 - 
1999. Pada tahun 2000 jumlah tersebut mengalami penurunan sebesar 5,27\% kemudian tahun 2001 penurunan mencapai 2,84\%. Pada tahun 2018 mengalami kenaikan mencapai 14\% (Sari \& Nuqul, 2017:38). Data statistik Pemasyarakatan yang bersumber dari Sistem Database Pemasyarakatan 2020 menyatakan bahwa sebanyak 35.044 narapidana adalah residivis atau $12,96 \%$ dari jumlah keseluruhan narapidana di Indonesia. Direktur Jenderal Pemasyarakatan, Reynhard Silitonga menyatakan bahwa selama pandemi Covid-19 ini, dari puluhan ribu narapidana yang mendapatkan asimilasi dan integrasi, sebanyak 95 narapidana melakukan pelanggaran, dimana sebagian besar adalah pelanggaran persyaratan umum. Pada Bapas Jakarta Selatan sampai bulan Januari 2021 telah menangani 1165 klien

Data diatas menggambarkan bahwa sebenarnya masih ada mantan narapidana yang kembali melanggar hukum, atau dengan kata lain selama menjadi klien dan menjalankan masa integrasi atau asimilasi, klien tersebut luput dari pengamatan Balai Pemasyarakatan. Hal ini memunculkan pertanyaan mengenai bagaimana pelaksanaan pembimbingan terhadap klien asimilasi selama pandemi Covid-19, bagaimana kendala yang dihadapi dan bagaimana upaya untuk mengoptimalisasi bimbingan terhadap klien Bapas. Penelitian ini dilakukan di Balai Pemasyarakatan Kelas I Jakarta Selatan dan merupakan penelitian deskriptif dengan metode penelitian kualitatif. Teknik pengumpulan data yang digunakan adalah wawancara, observasi, dan studi kepustakaan. Pengambilan subyek penelitian menggunakan teknik purposive sampling yaitu ditetapkan atas dasar tujuan tertentu yang mempunyai hubungan erat dengan masalah yang diteliti, yaitu Kepala Subseksi Bimbingan Klien Dewasa, Pembimbing Kemasyarakatan dan Klien Pemasyarakatan. Teknik keabsahan data menggunakan cross check dari hasil wawancara dan studi kepustakaan. Analisis data yang digunakan menggunakan analisis induktif dengan tahap reduksi data, unitisasi dan kategorisasi, serta pengambilan kesimpulan Dengan adanya penelitian ini, diharapkan dapat menjelaskan pelaksanaan pembimbingan pada klien pemasyarakatan serta upaya optimalisasi program tersebut di Balai Pemasyarakatan, faktor apa yang menghambat bimbingan klien pemasyarakatan 
dalam masa pandemi Covid-19 pada Balai Pemasyarakatan, bagaimana upaya untuk mengoptimalkan program bimbingan klien dalam masa pandemi Covid19 pada Balai Pemasyarakatan.

Pendekatan yang digunakan pada penelitian ini adalah pendekatan kualitatif. Menurut Creswell dalam kualitatif merupakan sebuah pendekatan atau penelusuran guna mengkeskplorasi dan mendalami suatu gejala sentral, untuk memahami gejala tersebut, peneliti melakukan wawancara informan dengan mengajukan pertanyaan yang bersifat umum dan luas (Semiawan, 2010:57). Bodan dan Taylor dalam data yang diperoleh dari penelitian kualitatif berupa data deskriptif yaitu kata-kata tertulis yang bersumber dari informan serta perilaku yang bisa diamati (Barlian, 2016:76).

Penelitian ini meggunakan desain penelitian deskriptif. Penelitian deskriptif merupakan penelitian yang dilakukan untuk menghimpun data aktual dan faktual kemudian mendeskripsikannya secara sistematis, serta mengidentifikasi permasalahan atau mengecek kondisi dan praktek-praktek yang berlangsung (Suryana, 2012:57). Model penelitian yang digunakan adalah Studi kasus yaitu proses pemgumpulan data dan informasi secara mendalam, mendetail, intensif, holistic, serta sistematis mengenai individu, peristiwa, latar sosial, maupun kelompok dengan menggunakan berbagai macam metode dan teknik serta sumber nformasi guna memahami secara efektif bagaimana orang, kejadian, latar sosial tersebut beroperasi atau berfungsi sesuai dengan konteksnya.

Data yang diperoleh dari penelitian ini bersumber dari hasil wawancara dengan beberapa informan, kegiatan observasi, serta studi dokumen. Untuk menentukan informan pada riset ini, peneliti menerapkan metode purposive sampling yaitu penentuan sampel yang berdasarkan pada rekomendasi target penelitian yang telah ditetapkan sehingga teknik ini tidak mempertimbangkan prinsip keterwakilan populasi (Barlian, 2016:82). Pada penelitian ini, informan yang ditentukan meliputi petugas pembimbing kemasyarakatan, klien pembebasan bersyarat serta tokoh masyarakat tempat klien melaksanakan pembebasan bersyarat. Pada penelitian ini teknik pengumpulan data dilakukan dengan wawancara, observasi lapangan dan studi pustaka terkait. Teknik analisis 
data yang digunakan pada penelitian ini adalah teknik analisis data induktif di mana merupakan pengambilan kesimpulan berdasarkan fakta-fakta khusus, kondisi konkret dan kemudian disimpulkan secara umum (Barlian, 2016:54).

\section{Pembahasan}

Menurut Keputusan Menteri Kehakiman RI No : M.01-PK.04.10 Tahun 1998 tentang Tugas, Kewajiban, dan Syarat-syarat bagi Pembimbing Kemasyarakatan dinyatakan bahwa Pembimbing Kemasyarakatan adalah pegawai/petugas Pemasyarakatan pada Balai Pemasyarakatan yang ditunjuk dan atau diangkat menjadi Pembimbing Kemasyarakatan serta dapat diberhentikan oleh Menteri sesuai dengan peraturan perundang-undangan yang mengaturnya. Pembimbing Kemasyarakatan dapat dikatakan juga sebagai Pekerja Sosial dalam bidang Kehakiman. Pembimbing Kemasyarakatan yang disebut Probation Officer, Parole Officer, dan After Care Officer yang memiliki disiplin ilmu tentang Pekerjaan Sosial disamping disiplin ilmu lainnya dalam usaha pelaksanaan bimbingan klien secara terpadu.

Melalui observasi yang dilakukan terhadap proses pelaksanaan bimbingan, pembimbing kemasyarakatan menerapkan prinsip-prinsip pekerjaan sosial. Pembimbing kemasyarakatan sebagai pekerja sosial di bidang pemasyarakatan memiliki peran antara lain memberikan motivasi pada klien, memberikan kesempatan pada klien untuk mengungkapkan perasaan, menyediakan informasi, membantu dalam pengambilan keputusan dan pemahaman situasi, menyediakan bantuan untuk menciptakan perubahan lingkungan sosial, serta memberikan bantuan untuk merestrukturisasi pola tingkah laku. Sementara menurut pakar ilmu pekerjaan sosial, peran dibagi menjadi tiga tingkatan yaitu mikro, mezzo, dan makro dimana pada masing-masing area membutuhkan peran yang sesuai.

Pelaksanaan bimbingan tersebut harus melalui sebuah assessment/ penilaian kebutuhan narapidana agar program bimbingan yang diberikan bisa tepat sasaran. Program bimbingan klien oleh Pembimbing Kemasyarakatan didasarkan pada hasil analisis kebutuhan klien dan terbagi menjadi tiga tahapan 
yaitu (Peraturan Pemerintah Nomor 31 Tahun 1999 Tentang Pembinaan Dan Pembimbingan Warga Binaan Pemasyrakatan) :

1) Bimbingan tahap awal, meliputi :

a) Penelitian kemasyarakatan

b) Penyusunan rencana program bimbingan

c) Pelaksanaan program pembimbingan

d) Penilaian penerapan program tahap awal dan pembuatan agenda bimbingan tahap lanjutan

2) Bimbingan tahap lanjutan, meliputi :

a) Penerapan program bimbingan

b) Penilaian program tahap lanjutan dan pembuatan agenda bimbingan tahap akhir

3) Bimbingan tahap akhir, meliputi :

a) Penerapan program bimbingan

b) Memeriksa dan memberikan penilaian pada keseluruhan hasil penerapan program bimbingan

c) Menyiapkan klien untuk menghadapi akhir masa bimbingan dan memperhitungkan akan peluang pemberian pelayanan bimbingan tambahan (after care)

\section{A. Pelaksanaan Bimbingan Klien Pemasyarakatan oleh Pembimbing Kemasyarakatan dalam Masa Pandemi Covid-19 pada Balai Pemasyarakatan Kelas I Jakarta Selatan}

Pelaksanaan pembimbingan pada sampel klien pemasyarakatan yang menjalani program integrasi dan asimilasi pada Balai Pemasyarakatan Kelas I Jakarta Selatan selama masa pandemi Covid-19 dapat diamati dari pelaksanaan pembimbingan kepada dua orang klien yaitu MF dan DZ. Pertama, klien MF telah melanggar UU RI Nomor 17 Tahun 2016 tentang Perlindungan Anak dan diputus pidana penjara selama 5 tahun dengan denda sebesar Rp 3.000.000,subsider 3 bulan. Berdasarkan Keputusan Menteri Hukum dan Hak Asasi Manusia RI Nomor M.HH-19.PK.01.04.04 Tahun 2020 tentang pengeluaran 
dan Pembebasan Narapidana dan Anak melalui Asimilasi dan Integrasi dalam rangka Pencegahan dan Penanggulangan Penyebaran Covid-19 klien tersebut mendapatkan hak asimilasi dirumah mulai tanggal 2 April 2020. Selama menjalani asimilasi dirumah klien melaksanakan asimilasi dengan baik sampai masa $2 / 3$ nya sehingga telah memenuhi persyaratan substantif dan administratif dalam pengusulan Pembebasan Bersyarat hingga masa pidananya berakhir pada tanggal 19 Mei 2023. Kedua, klien DZ melakukan penyalahgunaan narkoba dan melanggar UU Narkotika Pasal 127 ayat (1) UURI Nomor 35 Tahun 2009 dan diputus dengan pidana penjara selama 1 tahun 8 bulan. pada tanggal 28 Mei 2020 klien mendapatkan hak untuk menjalankan asimilasi dirumah dan melaksanakan bimbingan di Balai Pemasyarakatan Kelas I Jakarta Selatan berdasarkan Keputusan Menteri Hukum dan Hak Asasi Manusia RI Nomor M.HH-19.PK.01.04.04 Tahun 2020 tentang pengeluaran dan Pembebasan Narapidana dan Anak melalui Asimilasi dan Integrasi dalam rangka Pencegahan dan Penanggulangan Penyebaran Covid-19 hingga 2/3 masa pidananya. Selanjutnya, klien DZ mendapatkan usulan integrasi hingga masa pidana dan percobaannya berakhir pada 15 Maret 2021. Melalui sampel dua orang klien diatas, proses pembimbingan dilakukan dengan beberapa perubahan kebijakan yang tertuang dalam Keputusan Menteri Hukum dan Hak Asasi Manusia RI Nomor M.HH-19.PK.01.04.04 Tahun 2020, dengan begitu meskipun tidak maksimal namun proses pembimbingan harus tetap berjalan dan tetatp mengedepankan aspek kesehatan dengan mematuhi protokol kesehatan.

Proses pembimbingan pada masa pandemi Covid-19 ini, juga dilaksanakan terbagi menjadi 3 tahapan, namun terdapat sedikit perubahan pada mekanisme proses pembimbingan. Tahapan dijelaskan sebagai berikut :

\section{Pembimbingan Tahap awal}

\section{a. Penerimaan dan Pendaftaran Klien}

Penerimaan dan pendaftaran yang dulunya dilakukan secara langsung kini dilaksanakan secara daring (dalam jaringan) melalui email yang dikirimkan oleh pemohon kepada Balai Pemasyarakatan Kelas I Jakarta Selatan. Serah terima klien dilakukan melalui video 
conference setelah petugas mempelajari berkas serah terima klien yaitu surat keputusan asimilasi/integrasi, berita acara serah terima, lembar sidik jari, foto (tampak depan, belakang, dan samping). Sedangkan untuk berkas penelitian kemasyarakatan diganti dengan Laporan Perkembangan Pembinaan (LPP) selama narapidana berada di Lembaga Pemasyarakatan atau Rumah Tahanan. Laporan Perkembangan Pembinaan merupakan dokumen yang wajib dimiliki untuk pengajuan program integrasi atau asimilasi. Laporan Perkembangan Pembinaan dibuat oleh Wali Pemasyarakatan yang berisikan tentang identitas Warga Binaan Pemasyarakatan, jenis-jenis kegiatan yang diikuti oleh narapidana yang bersangkutan, serta perkembangan narapidana selama menjalani pembinaan di Lembaga Pemasyarakan. Laporan tersebut harus disusun dengan benar dan faktual sehingga data yang diperoleh adalah informasi yang valid dan bisa digunakan oleh Pembimbing Kemasyarakatan untuk menyusun program pembimbingan.

b. Pembuatan penelitian kemasyarakatan sebagai bahan penyusunan perencanaan program bimbingan

Selama masa pandemi Covid-19 proses penggalian informasi terkait klien dilakukan secara daring. Setelah Pembimbing Kemasyarakatan mempelajari dokumen klien yang dikirim oleh instansi pemohon (Lembaga Pemasyarakatan / LPKA / Rumah Tahanan Negara / Kepolisian), Pembimbing Kemasyarakatan melakukan koordinasi dengan instansi pemohon untuk menentukan waktu pelaksanan wawancara dengan klien secara daring untuk memperoleh data yang dibutuhkan dalam penyusunan litmas antara lain : riwayat hidup klien, latar belakang tindak pidana, kondisi keluarga/penjamin dan lingkungan tempat tinggal klien. sedangkan untuk kegiatan observasi terhadap kondisi tempat tinggal klien/penjamin serta lingkungan sekitarnya dilakukan dengan media video call dan bukti dokumentasi berupa foto atau video. 


\section{c. Penyusunan program bimbingan}

Dari hasil observasi lapangan dan wawancara peneliti dengan petugas Pembimbing Kemasyarakatan Balai Pemasyarakatan Kelas I Jakarta Selatan, bentuk progam bimbingan tahap awal pada masa pandemi Covid-19 meliputi pembimbingan kepribadian menggunakan metode casework (bimbingan perseorangan), pembimbingan kepribadian menggunakan metode groupwork (bimbingan kelompok), dan bimbingan kemandirian dengan meminialisir kontak dengan klien.

\section{d. Pelaksanaan program bimbingan}

Terkait pemberian bimbingan kepribadian utuk klien MF dan DZ yang dilakukan secara daring. Pembimbing kemasyarakatan secara rutin memberikan materi bimbingan seperti menyampaikan makna dari beberapa ayat pada Kitab Suci Al-Quran serta hadizt yang berkaitan dengan kehidupan sehari-hari, serta mengarahkan klien untuk selalu menjalankan ibadah sholat wajib dengan disiplin. Setiap seminggu sekali, klien tidak hanya sekedar menghubungi petugas Pembimbing Kemasyarkatan, namun juga mengirimkan ,foto kegiatan sehari-hari seperti kegiatan mengaji Al-Quran dan hafalan bacaan sholat. Kegiatan positif lainnya yang dilakukan oleh klien adalah bercocok tanam pohon durian dan tembakau di kebun milik keluarganya. Selain itu, Pembimbing kemasyarakatan selalu mengingatkan klien untuk tetap menaati peraturan yang berlaku di Balai Pemasyarakatan Kelas I Jakarta Selatan. Selain itu di setiap bimbingan konseling online,Pembimbing Kemasyarakatan selalu menyampaikan pesanpesan yang mengandung nilai-nilai moral kebaikan. Pelaksanaan pembimbingan secara online ini sebenarnya memiliki beberapa kelebihan antara lain klien MF dan DZ dapat merasa bebas dalam mengungkapkan diri mereka. Jarak fisik yang diberikan sebagai upaya untuk mencegah penularan Covid-19 ini menimbulkan kedekatan emosional yang membuat klien tersebut merasa aman 
dan bebas dari rasa takut dan malu.

\section{e. Pengendalian pelaksanaan program bimbingan tahap awal}

Pelaksanaan pengawasan klien pemasyarakatan pada masa pandemi Covid-19 dilakukan melalui daring. Untuk klien yang menjalani integrasi wajib menghubungi Pembimbing Kemasyarakatan satu bulan sekali, sedangkan untuk klien asimilasi di rumah wajib melakukan konseling kepada Pembimbing Kemasyarakatan satu minggu sekali. Kegiatan lapor diri tersebut berguna untuk memastikan keberadaan klien, memantau kegiatan sehari-hari klien selama menjalani program asimilasi maupun integrasi, hubungan dengan keluarga dan lingkungan, serta kondisi kesehatan klien. Pengawasan juga dilakukan secara langsung dengan mendatangi tempat tinggal klien. Kegiatan ini dilakukan untuk mengetahui bagaimana respons dan perilaku klien di masyarakat melalui persepsi masyarakat sekitar (keluarga, tokoh masyarakat, pemerintah daerah setempat, maupun kelompok masyarakat) terhadap klien tersebut. Selain itu pengawasan secara langsung dilakukan ketika terdapat klien yang sulit untuk dihubungi atau telah lebih dari 3 kali tidak melakukan konseling sehingga perlu dilakukan pengawasan yang lebih mendalam untuk memastikan klien yang bersangkutan tidak melanggar hukum.

\section{Pembimbingan Tahap Lanjutan}

Setelah menjalani 1/4 masa bimbingan, Pembimbing Kemasyarakatan melakukan evaluasi terhadap pelaksanaan program bimbingan tersebut. Berdasarkan wawancara dengan Pembimbing Kemasyarakatan yang menangani MF dan DZ, kedua klien tersebut cukup menunjukkan perkembangan yang baik. Dari hasil video call melalui aplikasi whatsapp dan foto yang dikirimkan oleh klien, menunjukkan mereka menjalani rutinitas beribadah dan aktivitas sehari-hari seperti bercocok tanam serta bekerja di sawah dengan cukup baik. Selanjutnya hasil asesmen tersebut dituangkan dalam penelitian kemayarakatan (litmas) bimbingan lanjutan dan di diskusikan dalam Sidang Tim Pengamat Pemasyarakatan (TPP). 
Dalam sidang TPP tersebut, Pembimbing Kemasyarakatan mendapatkan masukan dan dukungan dari peserta sidang TPP agar Pembimbing Kemasyarakatan konsisten dengan program bimbingan sebagaimana yang telah disepakati pada saat sidang TPP diawal masa bimbingan klien.

\section{Pembimbingan tahap akhir}

Memasuki tahap akhir bimbingan klien, maka berdasarkan apa yang telah berhasil dicapai pada pembimbingan tahap awal dan lanjutan serta berdasarkan pada rencana pembimbingan tahap akhir yang telah disusun dan disetujui dalam sidang Tim Pengamat Pemasyarakatan (TPP), maka Pembimbing Kemasyarakatan kembali berusaha untuk menuntaskan persoalan yang dihadapi klien. Pada tahap ini, Pembimbing Kemasyarakatan melakukan kunjungan rumah / home visit ke tempat tinggal klien untuk memantau perkembangan klien selama menjalani masa pembimbingan di lingkungan keluarga dan masyarakat.

\section{B. Faktor Penghambat Pelaksanaan Bimbingan Klien Pemasyarakatan pada Masa Pandemi Covid-19 di Balai Pemasyarakatan Kelas I Jakarta} Selatan.

Masalah yang dialami dirasakan oleh penyelenggara tugas membimbing dan mengawasi klien pemasyarakatan dalam rangka menyelenggarakan tugas pokok Balai Pemasyarakatan Kelas I Jakarta Selatan meliputi faktor internal dan eksternal. Kedua faktor tersebut dijelaskan sebagaimana uraian dibawah ini :

\section{Hambatan Internal}

\section{a. Keterbatasan informasi untuk asesmen}

Selama masa pandemi Covid-19 proses perencanaan program pembimbingan bagi klien asimlasi dan integrasi terkendala pada terbatasnya infomasi yang diperoleh dalam pelaksanaan assessment kebutuhan (need assessment). Akibat adanya kebijakan physical distancing yang ditetapkan oleh pemerintah dimana kebijakan tersebut menghimbau semua instansi untuk mengurangi kegiatan kontak 
langung sebagai upaya pencegahan penularan Covid-19, maka proses assessment dilakukan secara daring. Hal ini menyebabkan data yang diperoleh hanya berasal dari klien dan penjamin dengan cara menghubungi klien tersebut melalui nomor telepon yang tertera pada Laporan Perkembangan Pembinaan, sedangkan penggalian informasi dari masyarakat kurang terakomodir. Informasi dari klien dan penjamin dirasa kurang representative untuk meggambarkan kondisi klien karena terdapat kemungkinan klien yang bersangkutan menutup kondisi mereka sehingga hasil assessment kebutuhan menjadi kurang valid.

\section{b. Rendahnya kesadaran Pembimbing Kemasyarakatan dalam} pembuatan Laporan Perkembangan Pembimbingan Klien

Tidak semua Pembimbing Kemasyarakatan menyusun laporan perkembangan pembimbingan klien. padahal, laporan tersebut sangat penting untuk mengetahui perkembangan proses pembimbingan, apakah klien menunjukkan perubahan yang positif atau justru negatif. Selain itu Laporan Perkembangan Pembimbingan juga berfungsi untuk mengetahui perkembangan akan faktor-faktor kriminogenik selama menjalani masa bimbingan. Dibutuhkan Pembimbing Kemasyarakatan dengan pengetahuan dan pemahaman yang cukup terkait pentingnya hal tersebut (baik dari segi pengalaman maupun latar belakang pendidikan) sehingga setiap pentahapan bimbingan klien dapat berjalan dengan optimal.

c. Keterbatasan pemahaman petugas Lapas-Rutan akan pentingnya asesmen untuk penyusunan Penelitian Kemasyarakatan

Lembaga Pemasyarakatan dan Rumah Tahanan Negara kurang memahami bahwa assessment merupakan inti dari peri kehidupan narapidana selama menjadi warga binaan pemasyarakatan karena didalam assesment mencakup faktor-faktor yang mempengaruhi, dan latar belakang permasalahan yang ada pada narapidana. Hasil dari penelitian tersebut dijadikan rekomendasi dan solusi kebutuhan permasalahan narapidana supaya narapidana tersebut dapat hidup 
secara normal. Kendala dalam pelaksanaan asesmen secara online adalah PK kesulitan untuk menghubungi narapidana yang akan dibuatkan litmas akibat kurangnya koordinasi antara Lembaga Pemasyarakatan-Rumah Tahanan Negara dan Balai Pemasyarakatan. Pihak Lembaga Pemasyarakatan dan Rumah Tahanan Negara belum sepenuhnya memfasilitasi kegiatan asesmen secara online sehingga petugas PK harus datang langsung mengunjungi narapidana yang bersangkutan.

\section{Hambatan Eksternal}

Pelaksanaan pembimbingan selama masa pandemi Covid-19 pada Balai Pemasyarakatan Kelas I Jakarta Selatan terkendala pada tingkat kedisiplinan klien yang masih rendah dalam melakukan bimbingan secara online yang diakibatkan karena keterbatasan sarana. Terdapat beberapa klien yang tidak memiliki nomor telepon dan/ atau smartphone yang mendukung aplikasi video call sehingga menyulitkan Pembimbing Kemasyarakatan untuk melakukan bimbingan. Selain itu, terdapat beberapa nomor telepon klien yang tercantum pada Laporan Perkembangan Pembinaan tidak aktif sehingga kegiatan observasi keadaan atau kondisi klien dan lingkungan sekitar yang dilakukan secara daring juga belum efektif alhasil masih ada klien yang luput dari pengawasan.

\section{Optimalisasi program bimbingan klien pemasyarakatan dalam masa pandemi Covid-19 pada Balai Pemasyarakatan Kelas I Jakarta Selatan}

Terdapat beberapa masalah yang perlu mendapatkan perhatian dan pemecahan masalahnya, maka perlu adanya upaya untuk memperkecil hambatan baik yang berasal dari faktor internal maupun eksternal. Upaya untuk mengurangi hambatan pelaksanaan bimbingan dan pengawasan klien pemasyarakatan pada Balai Pemasyarakatan Kelas I Jakarta Selatan diuraikan sebagai berikut :

\section{Meningkatkan koordinasi dengan Aparat Penegak Hukum}

Pembimbing Kemasyarakatan perlu meningkatkan koordinasi dengan 
Aparat Penegak Hukum sebagai upaya untuk mendapatkan kontak/akses ke Kantor Kelurahan/Desa sehingga proses assessment tetap dapat berjalan walaupun dilaksanakan secara daring. Karena proses asesmen dilaksanakan secara daring, apabila Pembimbing Kemasyarakatan tidak memiliki kontak/akses dari pihak pemerintah desa setempat, maka Pembimbing Kemasyarakatan bisa menghubungi Kepolisian Resort (POLRES) Kota/Kabupaten tempat tinggal klien. selanjutnya dari pihak POLRES akan memfasilitasi petugas untuk bisa berkoordinasi dengan Kepolisian Sektor setempat. Di dalam struktur organisasi kepolisian terdapat sebuah sub bagian yang dinamakan Bhambinkamtibmas (Bhayangkara Pembina Keamanan dan Ketertiban Masyarakat). Bhabinkamtibmas merupakan bagian dari Kepolisian Republik Indonesia yang memiliki fungsi untuk membina keamanan serta ketertiban di masyarakat pada tingkat desa/ kelurahan (Surya, 2020:25) .

\section{Peningkatan SDM Pembimbing Kemasyarakatan}

Beberapa upaya yang dapat dilakukan untuk meningkatkan kesadaran petugas Pembimbing Kemasyarakatan dalam pembuatan Laporan Perkembangan Pembimbingan Klien adalah dengan memberikan pendalaman materi terkait revitalisasi pemasyasrakatan serta menjelaskan urgensi dari pembuatan Laporan Perkembangan Pembimbingan kepada Pembimbing Kemasyarakatan pada setiap tahapan narapidana sehingga program revitalisasi bisa berjalan lebih optimal. Solusi lain yang bisa dilakukan adalah dengan melakukan monitoring terhadap kinerja petugas Pembimbing Kemasyarakatan untuk memacu produktivitas petugas. Penguatan sumber daya manusia pada Balai Pemasyarakatan Kelas I Jakarta Selatan perlu dilakukan untuk mengoptimalkan fungsi dari organisasi. Upaya penguatan sumber daya manusia terutama petugas Pembimbing Kemasyarakatan dapat dilakukan dengan cara ikut serta dalam pendidikan dan pelatihan (diklat) profesi Pembimbing Kemasyarakatan. Walaupun dalam masa pandemi Covid-19, Pembimbing Kemasyarakatan tetap bisa mengikuti diklat penunjang profesi secara daring melalui 
kegiatan webinar dengan tema-tema yang relevan seperti :bimbingan konseling, pengenalan psikotropika, konseling untuk korban penyalahgunaan narkoba, advokasi sosial, serta pendampingan psikologi $\mathrm{ABH}$.

\section{Meningkatkan koordinasi antara Lapas-Rutan-Bapas}

Agar proses asesmen online untuk penyusunan litmas dapat berjalan dengan baik, maka perlu adanya peningkatan koordinasi antara Lapas Rutan-Bapas terkait kebijakan pelaksanaan asesmen selama pandemi. Bentuk koordinasi bisa dilakukan melalui virtual meeting yang melibatkan petugas dari masing-masing Unit Pelaksana Teknis Pemasyarakatan. Pihak Balai Pemasyarakatan juga bisa menyampaikan tentang pentingnya pembuatan litmas di setiap tahapan pembinaan dan pembimbingan narapidana. Solusi lain yang dapat dikukan adalah dengan menempatkan petugas Pembimbing Kemasyarakatan serta mengoptimalkan POS BAPAS pada setiap Lembaga Pemasyarakatan dan Rumah Tahanan Negara untuk mempermudah Balai Pemasyarakatan dalam menjalankan tugas-fungsinya.

\section{Penutup}

\section{A. Kesimpulan}

Berdasarkan penelitian yang telah dilaksanakan berkaitan dengan upaya optimalisasi bimbingan klien Pemasyarakatan dalam masa pandemi Covid-19 pada Balai Pemasyarakatan Kelas I Jakarta Selatan, maka dapat diambil beberapa kesimpulan sebagai berikut :

1. Pelaksanaan pembimbingan pada masa pandemi sedikit banyak mengalami berbagai perubahan. Hal ini terkait erat dengan proses interaksi langsung antara klien dan petugas Bapas yang sangat dibatasi.

2. Selama masa pandemi, segala tahapan proses pembimbingan klien dilakukan secara daring (dalam jaringan). Pembimbingan dilakukan secara rutin satu minggu sekali melalui aplikasi whatsapp. Klien pemasyarakatan wajib menghubungi petugas PK untuk melakukan bimbingan. Hal tersebut dilakukan untuk tetap menjalankan amanat Undang-undang khususnya PP Nomor 31 Tahun 1999, meskipun dalam keadaan pandemi. 
3. Terdapat beberapa kendala dalam proses pembimbingan selama masa pandemi Covid-19 antara lain terbatasnya informasi (nomor telepon dan alamat rumah penjamin), mnimnya media komunikasi (HP atau smartphone) yang dimiliki oleh klien, kurangnya kedisiplinan PK akan pentingnya pembuatan Laporan Perkembangan Pembimbingan, keterbatasan pemahaman petugas Lapas-Rutan akan pentingnya asesmen.

\section{B. Saran}

1. Perlu adanya peningkatan koordinasi antara petugas Balai Pemasyarakatan Kelas I Jakarta Selatan dengan Aparat Penegak Hukum sehingga kegiatan pembimbingan serta pengawasan yang dilakukan secara daring terhadap klien dapat berjalan dengan baik sehingga klien pemasyarakatan dapat kembali ke masyarakat dan hidup secara normal. Pembimbing Kemasyarakatan harus memastikan validitas nomor handphone klien yang tertera Laporan Perkembangan Pembinaan WBP dan benar-benar dapat dihubungi guna kelancaran proses pembimbingan secara online serta meningkatkan koordinasi dengan Aparat Penegak Hukum dan Pemerintah Daerah setempat untuk dapat mendukung program pembimbingan dan ikut serta dalam proses pengawasan klien selama menjalani asimilasi maupun integrasi.

2. Peningkatan sinergitas antara Rumah Tahanan Negara-Lembaga Pemasyarakatan-Balai Pemayarakatan serta menempatkan petugas Pembimbing Kemasyarakatan pada setiap Lembaga Pemasyarakatan dan Rumah Tahanan Negara perlu dilakukan untuk mewujudkan proses Pemasyarakatan yang efektif dan efisien.

3. Dalam kondisi pandemi Covid-19 dibutuhkan adanya perhatian khusus dari pemerintah khususnya Direktorat Jenderal Pemasyarakatan untuk memberikan pembekalan berupa e-learning kepada Pembimbing Kemasyarakatan mengenai hal-hal yang berhubungan dengan pembimbingan online untuk menciptakan Pembimbing Kemasyarakatan yang berkualitas sehingga walaupun proses pembimbingan klien dilakukan secara daring, namun tidak mengurangi kualitas dari pembimbingan tersebut. 


\section{Daftar Pustaka}

Barlian, E. (2016). Metodologi Penelitian Kualitatif \& Kuantitatif. Padang: Sukabina.

Caplan, J. M. (2015). Conflicting models of casework and surveillance. Federal Probation, 70(3). Diambil dari https://www.ojp.gov/ncjrs/virtuallibrary/abstracts/parole-system-anomie-conflicting-models-casework-andsurveillance

Hamzah, A. (2016). KUHP dan KUHAP (10th ed.). Jakarta: Rineka Cipta.

Indradi, Havik, A. R. I. S. A., Arsyah, A. M., Mulyani, C. K., Athilla, K. D., Faruq, M. H. Al, ... Dinda, S. (2020). Politik Hukum Pemerintah dalam Penanganan Pandemi Covid-19. Diambil dari Universitas Gajah Mada website: demajusticia.org

Republik Indonesia. Peraturan Menteri Hukum dan HAM RI No.M.HH-19 PK.01.04.04 Tahun 2020 tentang Pengeluaran dan Pembebasan Narapidana dan Anak melalui Asimilasi dan Integrasi dalam rangka Pencegahan dan Penaggulangan Penyebaran Covid-19.

Republik Indonesia. Peraturan Pemerintah Nomor 31 Tahun 1999 Tentang Pembinaan dan Pembimbingan Warga Binaan Pemasyrakatan.

Sari, L. L., \& Nuqul, F. L. (2017). Pengaruh Harapan terhadap Kecenderungan Residivis pada Narapidana. Idea: Jurnal Psikologi, 1(1). Diambil dari http://repository.uin-malang.ac.id/2109/

Satgas Covid-19 Indonesia. (2021). Data Sebaran Covid-19 di Indonesia. Diambil dari https://covid19.go.id/

Semiawan, C. R. (2010). Metode Penelitian Kualitatif_Jenis, Karakteristik dan Keunggulannya. Jakarta: Grasindo.

Suryana. (2012). Metodologi Penelitian-Model Praktis Penelitian Kuantitatif dan Kualitatif. Bandung: Universitas Pendidikan Indonesia.

Wibowo, M. S. A. (2020). Pelaksanaan Proses Peradilan Dan Pemenuhan Hak Dalam Perlindungan Hukum Bagi Anak (Menurut UU No. 11 Tahun 2012 Tentang Sistem Peradilan Pidana Anak). Reformasi Hukum, XXIV(1). https://doi.org/10.46257/jrh.v24i1.90 